\title{
Bir Finansman Kaynağı Olarak Vakıflar: Osmanlı Örneği
}

\section{The Foundations as A Financial Resource: The Ottoman Example}

\section{Veli Sırım}

iktisat bölümü, Namık Kemal Üniversitesi, Tekirdağ, Türkiye

\section{Özet}

Osmanlı Devletinde eğitim ve sağlık hizmetleri ile dinî ve kültürel faaliyetlerin finansmanı için merkezî bütçeden doğrudan bir kaynak ayrımıyordu. Devlet bütçesinden herhangi bir kaynak ayrılmadığı halde zikredilen hizmetlerin finansmanı, günümüzde üçüncü sektör olarak adlandırılan, daha çok bağımsız iktisadî birimler şeklinde teşkilatlanmış olan vakıflar aracııı̆ıyla gerçekleştiriliyordu. Öyle ki, vakıf gelirlerinin Osmanlı malî sistemi içindeki oranı XVI. yüzyılın başlarında yaklaşık \%12'lik bir paya sahip iken, bu oran XVII. yüzyılın başlarında \%20'lere kadar yükselmişti.

Dolayısıyla vakıfların, kâr imkanı bulunmayan ya da kâr marjının düşük olması nedeniyle iktisadî açıdan yatırımın cazip olmadığı eğitim, sağlık, kültürel ve dinî faaliyetlerin finansmanında önemli bir rol oynadığı söylenebilir.

Her hayrî müessesenin bir vakfiyesi bulunmakta ve bu vakfiyede müessesenin çalışma şekli ile hayır faaliyetlerinin yürütülmesi için yapılacak masrafları karşılayacak yapılar, vakıflar tek tek ifade edilmekteydi. Vakfiyede ayrıca vâkıfın (vakfı kuran kimsenin) şartlarına göre kurumun nası işleyeceği, kimlerin istihdam edileceği ve ne kadar maaş alacakları gibi konular yer alırdı.

Bu makalede, Osmanlı döneminde bir finansman kaynağı olarak vakıfların oynadığı rol üzerinde durulacaktır.

Anahtar Kelimeler: Vakıf, Osmanlı Dönemi, Finansal Kaynak

JEL Sınıflandırması: A13, A14, B15, N00, N35

\section{Abstract}

In the Ottoman Empire, there was no direct funding from the central budget to finance education, health services and religious and cultural activities. In case of any insufficiency in the state budget for the services that have been mentioned above, they were provided by foundations which are currently referred as the third sector and are organized as more independent economic units. For instance, the ratio of foundations' income in the Ottoman financial system is approximately $12 \%$ at the beginning of the 16th century and it reached to $20 \%$ in the early 17 th century. Therefore, it can be stated that foundations play a significant role for finance for education, health, cultural and religious activities where profit is not available or the profit margin is low and the investment is not economically attractive.

Every charitable institution had a foundation and the working way of foundation and structures of foundation which will be responsible for expenses to meet requirements for charity activities were expressed one by one. The foundation also included subjects such as how the institution would work, who would be employed and how much salary would be earned with regarding the conditions of the foundation (and conditions of the person/founder who established the foundation).

This article will focus on the role of foundations as a source of funding in the Ottoman era. Keywords: Waqfs (Foundations), Ottoman Era, financial resource, social serves

JEL Classification: A13, A14, B15, N00, N35

CONTACT : Veli Sırım, vsirim@nku.edu.tr, ORCID ID: orcid.org/0000-0002-8130-6153 


\section{Giriş}

Vakfetme eylemi bir mülkü "menâfii insanlara ait olur vechiyle Allah'ın mülkü hükmünde olmak üzere temlik ve temellükten habs ve men etmek" (Berkî, 1940:40) veya "bir gayr-1 menkulün belli bir sosyal, hayrî amaçta kullanmak üzere vakfedenin mülkiyetinden ve özel mülkiyetten (bir daha alım-satıma konu olmaktan) çıkarılarak Allah'a (kamuya, topluma, ümmete) mâletmek" (Kozak, 1985:48) şeklinde tarif edilmiştir. Bu tariften de anlaşıldığı üzere vakıf, sadece Allah rızasını kazanmak için, zengin kimseler tarafından kurulan ve menfaati tamamıyla ihtiyaç içinde bulunanlara tahsis edilen müesseselerdir. Böyle bir müesseseyi kuran kimse, daha önce sahibi bulunduğu mülkü tamamen elinden çıkarıyor, onu Allah'ın mülkü haline getiriyor demektir. Bu temel prensiptendir ki, vakfı yapan kimse tekrar o mal üzerinde mülkiyet dava edemez. Vakfından geri dönmesi mümkün değildir (Kazıcı, 1985:28)

Vakıf kavramıyla ilgili yapılan tüm tanımlamalardaki ortak özelliğin, bir malın kamu hizmetine tahsis edilmesi oluşu dikkat çekicidir. Bu özellik ise, o kuruma sosyal içerik kazandırmaktadır. Çünkü vakıf kurumu kamuya yönelik faaliyet gösterdiğinden, kamu ihtiyaçlarını gidermeyi, karşılamayı amaç edindiğinden, ayrıca söz konusu kamu hizmetinden faydalanan kesimin insanlardan oluşması nedeniyle kurumla toplum arasındaki ilişki ilgili kuruma sosyal özellik kazandırmaktadır (Ertem, 2011:26).

Vakıf tesis eden kişiye "vâkıf" vakfedilen mala "mevkuf" denir. Vakıf yapan kişinin amaçlarını, şartlarını ihtiva eden, kurulacak vakfın nasıl yönetileceğine ilişkin esasları belirleyen ve mahkemece tesciliyle birlikte vakfın vücud bulduğu vesikaya (vakıf senedine) "vakfiye" adı verilir. Vakfın menfaati kendilerine tahsis ve şart olunan cihete fikhî tâbirle "meşrûtün leh" ve "mevkûfun aleyh" denir (Şahin, 1986:231) Bu bilgiden hareketle bir vakıf müessesinde,

1- Vâkıf (Vakfeden)

\section{2- Mevkûf (Vakfedilen)}

3- Mevkûfun aleyh veya Meşrûtun leh (Vakfın menfaatleri kendilerine tahsis olunan) unsurları mutlaka olmalıdır.

$\mathrm{Bu}$ üç unsurdan ikisini insanlar oluşturmaktadır. Gerek vakfeden gerek vakfın menfaati kendilerine tahsis olunanlar birey veya toplumdan oluşmaktadır. Her iki kesim arasındaki ilişki vakfedilen şeyle sağlanmaktadır. Bu açıdan ilişkinin boyutunu ve özelliğini daha çok vakfedilen şey ortaya koymaktadır. Ĕger vakfedilen şey yani mevkûf daha çok kamu hizmetine yönelik, toplumsal ihtiyaçları karşılar mahiyette ise vakıf müessesesi o derecede sosyal nitelik kazanmakta, bu mahiyetten uzaklaşıldığı oranda da sosyal niteliğini kaybetmektedir. Bu konuda örnek verilecek olursa (Osmanlıda) Fatih Sultan Mehmed'in sağlık vakfiyesi ile bütün toplum (gayr-i müslimler dahil); avârız vakıfları ile belli bir mahalle veya köy, aile vakıfları ile toplumsal kurumların en küçük grubu olan aile, vakfın menfaatlerinden yararlanan kesimi oluşturur. Görüldüğü üzere vakıfların hizmet alanları, hizmetin kapsamı ve hitap ettiği kitle, vakfın amacına bağlı şekillenmektedir (Ertem, 2011:27). 
İslâmın, yardımlaşma ile ilgili emir ve prensiplerinden doğan vakıf sistemi, asırlarca insanlığa hizmet etmiş dinî ve sosyal bir müessesedir. Esas çıkış noktası Kur'an ${ }^{1}$ ve Sünnette ${ }^{2}$ yer alan başkalarına yardım etme eksenli emir ve tavsiyeler olmuştur. Vakfın konusunu meydana getiren sadaka ve sadaka-i câriye, in'âm (nimet verme), it'âm (yedirme), ihsân (karşlıksız verme), karz (ödünç verme), sosyal yardımlaşma ve dayanışma, köle azat etme, yolcuları yedirip barındırma, sağlık ve temizlik hizmetlerinde bulunma gibi konularla ilgili âyet ve hadisler bu kurumun doğup gelişmesine yol açmıştır (Tabakoğlu, 2013:123).

Bu konuda gösterilebilecek en belirgin örnek ise Hazret-i Peygamber'in bir hadisinde zikredilen kişinin ölümden sonra dahi amel defterinin açık olacağı belirtilen "sadaka-i câriye" vurgusudur (Kazıc1, 1985:7). Hazret-i Peygamber bir hadis-i şerifinde Hazret-i Ömer'e şöyle buyurmuştur: "Bir şeyin aslını satılmamak üzere hayır vasıtası kıl. Yalnız mahsûlü harcansın ve sadaka olarak dağıtılsın." (Buhari, Hars, 14)

"Sadaka-i câriye" anlayışı, bir gayr-1 menkûlün vakfedilmesiyle katlanılan fedakârlığın bir defaya mahsus olmasıyla birlikte, vakıf tahsisinde bulunan kişiye hayrının sonsuza kadar devam edeceği fikri, vakıfların yaygınlaşmasında önemli rol oynamıştır.

Zira vakıf, münferit sadaka ve yardımlara muhalif olarak, âmmeye hem daha vâsi (geniş) yardım imkânı hazırlar, hem bu imkânı sürekli kılar. Bu yönüyle vakıfların iktisadî ve malî yardımlaşmada devamlılık ve verimlilik temin eden bir mahiyeti vardır ve amme hizmeti lehine döner sermaye tesis eden bir özelliği haizdirler (Berkî, 1969:3-4).

Öte yandan vakıf, ekseriyet itibariyle somut ve varlığı çeşitli türler itibariyle korunabilen bir kurum olması cihetinden de yaygınlaşmaya müsaittir (Atılgan, 1996:117)

Vakfın esası bir malı insanların faydalanması için, Allah'ın mülkü hükmünde olmak üzere, ferdî mülkiyet sahasından çıkarmaktır. Mallar, taşınır ve taşınmaz olarak ikiye ayrılır. Asıl vakıf ise, "akar" da denilen taşınmaz malların vakfıdır. Han, hamam, çarşı, zıraî topraklar gibi taşınmazların gelirleriyle hayır kurumlarının finanse edilmesi esas kabul edilmiştir. Bu vakıflar "Akar Vakıfları" olarak da anılmıştır (Berki, 1966:54). Bu müesseselere ilave olarak tarım işletmeleri, araziler üretim kaynakları olarak düzenli gelir sağladıkları gibi toprağın vergi gelirleri de bu amaçla kullanılmıştır. Köyler, karyeler, içindeki meskenler, tarlalar, çayırlar, kuyular, nehirler, vadiler... bütün hak ve hukukuyla vakfedilmiştir (Şensoy, 2016:47). Yine finanse edenlerden bir kısmı taşınır servet olabilir. $\mathrm{Bu}$ şekilde oluşan vakıf, sandıklar veya fonlar ile kredi faaliyetleri şeklinde işlev görür (Tabakoğlu, 2013:193). Netice itibariyle vakıflarda, finanse eden gelir kaynakları olan "asl1 vakıf" ile finanse edilen kurumlar yani "müessesât-1 hayriyye" söz konusudur (Yediyıldız, 1982:156)

Vakıf müessesesi, İslam'ın sınıflaşmayı önleyici vasfının bir örneği ve önemli bir pratiğidir. Vakıflar aracılığıyla, kişilerin gelir fazlaları, bizzat kendileri tarafından ve gönüllülük esasından hareketle, toplumun ihtiyaç sahibi kesime aktarılmıştır. İslam'ın lüks

\footnotetext{
1 Örnek. "Siz sevdiğiniz şeylerden (Allah yolunda) harcayıncaya kadar asla iyiliğe ermiş olmazsınız. Her ne infak ederseniz, şüphesiz Allah onu bilir." (Âl-i İmran, 3/92)

2 Örnek: "İnsan ölünce şu üç ameli kesilmez: Sadaka-i câriye, fayda veren ilim, kendisine duada bulunan Salih bir evlat." (Müslim, Sahih, Vasiyyet:14)
} 
ve israf yasakları ve infâkı teşvik etmesi, harcanabilir gelirleri vakıflar yoluyla, toplum refahının artmasına yöneltmiştir. Daha teknik bir anlatımla, tüketici rantı olarak ifade edilen mallara daha yüksek fiyat ödeyebilme takati, fiyat farklılaşması yoluyla lüks tüketime yönelerek israf edilmemiş, vakıflar aracılığıyla umumî refahın artmasına yardımcı olmuştur. Böylece, İslam tarihi boyunca, özellikle Selçuklular ve Osmanlılar zamanında lüks tüketime yönelmeyen tüketici rantları vakıflara akarak sosyal refahı yükselten yaygın bir sabit sermaye teşekkül etmiştir (Tabakoğlu, 2005:26, 205).

Sonuç olarak vakıflar, İslam toplumunun müşterek ve manevî servetini teşkil etmişlerdir. Vakıflar sayesinde bir takım servetler amme menfeatine tahsis edilmiş, böylece bu servetlerin meşrû suretle devamı ve tenmiyesi (verimlendirilmesi) emniyet altına alınmıştır (Bilmen, 1970:1/212)

\section{Osmanlı Klasik Döneminde Bir Finansman Kaynağı Olarak Vakıflar}

Osmanlı toplumunda Batı'da yaşanan sınıflaşmaya rastlanmamakla birlikte, sosyal dokunun meydana gelmesinde en azından iki grup insana ihtiyaç söz konusuydu: Bunlardan birisi memleketi ve sosyal nizamı muhafazaya mecbur olan yüksek devlet görevlileri (rical) grubu; diğeri ise, hizmetlerini yapabilmeleri için birincilere gerekli serveti temin etme görevini üstlenenlerin meydana getirdiği reâyâ idi. Bu yaklaşım ve ayırım aslında dinî bir bakış açısından kaynaklanmaktaydı ve kaçınılmazdı. Zira Kur'an-1 Kerim'de "Sizi yeryüzünün halifeleri yapan, size verdiği şeylerde, sizi denemek için, kiminizi kiminizden derecelerle üstün kılan O'dur." (En'am Suresi, 6/165) buyrulmuştur. $\mathrm{Bu}$ âyette de vurgulandığı üzere, sosyal yapıda insanların farklı servet ve güç sahibi konumunda olmaları doğrudan Allah'ın dilemesinin bir neticesidir ve bu farklılaşmanın asıl sebebi her iki kesimde de yer alan fertlerin imtihana tabi tutulmasıdır. İşte bu şuur ile hareket eden, özellikle varlıklı ve yüksek düzey idareci konumunda olan Osmanlı insanı, söz konusu varlık ve üstünlük imtihanında muvaffak olmak için, bilhassa vakıf müessesesi yoluyla dar gelirli insanlara yardımda bulunmayı şiar edinmişlerdir (Yediyıldız, 1982:145). Osmanlı toplumunda askerî sınıfa (padişahlar, sadrazamlar, ulema, tarikat şeyhleri ve vakıf yöneticileri) mensup kişilerin kurdukları vakıfların toplam vakıflar içindeki payının \%65.07 olması, kalan kısmını da raiyyet sınıfını meydana getirenlerin (çiftçiler, tüccarlar ve zanaatkarlar, âyân ve mesleksizler) kurdukları vakıflar olması (Yediyıldız, 1982:146) bunun açık göstergesidir.

Böylece vakıf müessesesi sayesinde üst tabakanın servetinin, onların mülkiyetinden çıkarak toplumsallaşması ve elde edilen gelirlerin alt tabakalara gelir ve hizmet şeklinde yayılması söz konusu olmuştur (Ertem, 2011:27) Vakıf sayesinde vakfeden kişiden alt gelir grubuna servet transferi bir defa olmakla birlikte, ancak gelir transferi vakıf yaşadıkça devam etmektedir (Zaim, 1987:210)

İslâmın geliştirip tarihe hediye ettiği bu önemli kurumu Osmanlılar başlangıçtan itibaren benimsemekte tereddüt etmemişlerdir. Hâkim oldukları bölgelerde daha önceki İslâm toplumlarının kurmuş olduğu vakıfları itina ile korumakla yetinmemişler; onu sosyal ve iktisadî hayatın hemen her alanında büyük bir yoğunlukta yaygınlaştırdılar, derinleştirdiler ve ona yeni boyutlar kazandırmışlardır (Genç, 2014:10). 
Osmanlı Devletinin daha ilk kuruluş yıllarından itibaren, İslam medeniyetinin bir mirası olarak alınan vakıf uygulamasının, devletin siyasi ve malî kudretinin inkişafına paralel olarak hem nicelik hem nitelik olarak arttı̆̆ını söyleyebiliriz. Bu istikamette yüzyıllar boyunca milyonlarca kilometrekarelik hakimiyet alanı dahilinde pek çok mescid, türbe, ribat, tekke, medrese, mektep, köprü, sulama kanalı, su yolu, kervansaray, hastane ve imaret gibi dinî ve hayrî tesis vakıf kurumu sayesinde vücuda getirildi. Orhan Gazi' den $^{3}$ başlamak üzere, Osmanlı padişahları, vezirleri, emirleri, zenginleri sayısız vakfı halkın hizmetine sundular. (Kazıcı, 1985:56-58) Vakıfların kurulmasına, korunmasına ve vakfiyelerindeki şartlarına göre işlemesine azami riayet ve hassasiyet gösteren Osmanll, fethedilen yerlerdeki vakıflara da asla dokunmamış, eskiden beri vâkıfın şartı ne ise ona aynen riayet etmişti. Daha önceden Müslüman idareci ve hükümdarların hakimiyeti altında bulunup Osmanlı sınırları dahiline katılan topraklarda var olan ve işleyen vakıfların şartları değiştirilmeden uygulanmaya devam edilmişti (Köprülü, 1942:22)

Osmanlı döneminde şehirlerin her türlü amme hizmetleri, içtimaî muavenet (sosyal yardımlaşma) teşkilatı, ilmî, dinî ve medenî hayatın her türlü tezahürleri vakıf tesisleri aracılığıyla tanzim ve idare edilmiştir. Bununla da kalınmamış, Osmanlı devleti idaresince bir iskân ve imar metodu olarak vakıflara önemli bir görev de yüklenmiştir (Barkan, 1942:354)

Osmanlı toplumunun tesisi ve işleyişinde, memleketin imar ve inşasında vakıfların rolü çok büyüktür. Günümüzde ancak, devlet teşebbüsü ve kaynaklarıyla yaptırılabilecek boyutta büyük ve umumî menfeatleri barındıran faaliyet ve yatırımlar, vakıflar aracılığıyla gerçekleştirilmiştir (Kazıcı, 1985:10). Vakıf sisteminin belki en güzel ve en orijinal özelliği pek çok beledî hizmetlerin ne hükümete, ne yerel belediye yönetim birimlerine, ne de halka malî bir yük getirmeden gönüllülük prensibiyle hareket eden bireyler tarafından yerine getirilmesi, halkın da bütün bu hizmetlerden tamamen parasız bir şekilde istifade etmeleridir. Bu müesseseleri yapanlar, sadece bunların inşâsına yönelik masraflarını değil, inşâsını müteakiben faaliyete geçmesiyle birlikte tüm giderlerini karşılayacak îrad ve akarlarını vakfiyeler aracılığıyla garanti altına almaktaydılar (Ergin, 1936:47) Zira çok büyük masraf gerektiren cami, medrese, kütüphane, mektep, imaret ve benzeri tesislerin inşâsını tasarrufları ile gerçekleştirdikten sonra bunların bakım ve yönetim giderlerini karşılamak üzere gelir getirici başka bir takım yatırımları yapmak da gerekiyordu. Ekonominin çeşitli sektörlerinde ihtiyaç duyulan ve küçük ölçekli üreticilerin tasarruf gücünü aşan imalathane, bina ve teçhizatlara yapılan bu yatırımlar, iktisadî hayatın devam edebilmesi için zorunlu, hayatî yatırımlardı. Bunlar, esnaf ve tüccara kiralanıyordu (Genç, 2014:15).

Osmanlı İmparatorluğu'nda yürürlükte olan Hanefi Mezhebi'ne göre topraklar, 3 yıllığına; diğer taşınmazlar ise 1 yıllığına kiralanmıştır. Zamanla değişen şartlara uyum sağlayabilmek için iki yeni kiralama yöntemi, mukataa ve icareteyn ortaya çımıştır. Mukataa, önceden belirlenmiş yıllık bir ücretle vakıf toprağın işletilmesi karşıllı̆̆ başkasına devir edildiği bir kira sözleşmesidir. Kiracı bu arazi üzerinde kendi özel mülkü olmak

3 Orhan Gazi'nin 724 Rebiülevvel (1324 Mart başı) tarihiyle azadlı kölelerinden Tavaşi Şerafeddin'e Mekece'de vakfettiği hankâh'ın tevliyetini verdiğine dair vakfiye ile vakfın şartlarını gösteren Farsça yazılmış tuğralı vesika için bkz. Kazıcı, 1985:56-58. 
kaydı ile binalar inşâ edebilmiş, hatta ağaçlar dikebilmiştir. Bunları vakıf haline bile dönüştürebilmiştir (Yediyıldız, 1986:158). Çift kiralama anlamına gelen, icareteyn yöntemi, işletilemeyecek hale gelmiş vakıf mülklerin kiralanmasında uygulanmıştır. Kiracı sözleşme anında icare-i muaccele denen peşin kira ödemiş; bu ödenen meblağ ile gereken onarım yapılmıştır. Kiracı ayrıca her yıl mütevelliye değişmeyen bir kira bedeli daha ödemiştir (Şensoy, 2016:48).

Bu yönleriyle vakıflar özellikle klasik dönem Osmanlı devletinde, bir sosyal güvenlik kurumu (Tabakoğlu, 2013:207) olmasının yanı sıra, fiilen maliyenin bir bölümü olmuştur. Zira yatırımların büyük kısmı hep vakıflar aracılığıyla gerçekleştirilmiştir. Osmanlı Devletinin malî teşkilatını oluşturan üç temel unsurdan (Merkez Maliyesi, Tımar Sistemi ve Vakıflar) birini teşkil ettiğini (Tabakoğlu, 1994:162, 202) düşünürsek, bugün bütçe içerisinde yer alan yatırım harcamalarının hemen hepsi vakıflar tarafından gerçekleştirildiğini söyleyebiliriz. Neredeyse bütün altyapı yatırımları, bayındırlık yatırımları, sosyal hizmet yatırımları, eğitim yatırımları, diyanet yatırımları vakıflar aracılığıyla hayata geçirilmiştir (Tabakoğlu, 2005:260)

Bu kurumlarda çalışanların maaşlarının ödenmesi, câri harcamalarının önemli bir bölümünü finanse etmesi nedeni ile de Osmanlı malî teşkilatının merkez maliyesi ve tımar sistemi ile birlikte üçüncü öğesi olarak gösterebiliriz. Bir başka deyişle ülkenin "gayr-i safi milli hasılası"nın önemli bir kısmını oluşturan, yukarıda da zikrettiğimiz, üç kesimden birisi olmuştur (Tabakoğlu, 2004:25).

Ömer Lütfi Barkan'ın 1530-1540 tarihleri arasındaki tahrirleri baz alarak yaptığ1 hesaplarda, Anadolu Eyaleti'nin toplam kamu gelirinin \%17'si, Rumeli Eyaleti'nin \%32 lik bölümü -Büyük sultan vakıflarının da içinde bulunduğu İstanbul ve civarı ile Doğu ve Batı Trakya, Güney Bulgaristan ve Makedonya bölgesinin oluşturduğu bu alanda- gibi bir oranı vakıflar tarafından kontrol edilen kamu gelirlerinden oluşmuştur (Barkan, 1962:242)

Osmanlı hakimiyeti altında inşâ edilip yüzyıllar boyunca hizmet veren sayısız han, köprü, kervansaray, çarşı, bedesten gibi kurumların, başta askeri zümre mensupları olmak üzere devlet erkânı ve diğer zengin şahıslara vakıflar aracılığıyla yapılmasına yönelik teşvik edilmesinin sebeplerinden bir diğeri, ticaretin canlandırılması idi. Artan ticaret ise Osmanlı hazinesi için artan vergi geliri anlamına geliyordu ki, bu Osmanlı iktisadî dünya görüşünün iki temel prensibinden biri olan fiskalizmin uygulamalı bir örneğini teşkil ediyordu (Genç, 2000:208).

Vakıflar, aynı zamanda Osmanlı şehrinin oluşum ve gelişmesinde önemli bir rol üstlendiği söylenebilir. Genellikle her yerleşim merkezinde bir cami ve o camiin etrafında oluşturulan medrese, kütüphane gibi eğitim kurumlarıyla hastane, hamam, aşevi gibi çeşitli hayır kurumları inşâ ediliyor ve bu kurumlar vakfın oluşturulmasının ana hedefini teşkil ediyordu. Bu kurumların tüm gider ve harcamalarını finanse etmek için de yine vakıf içinde yer verilen han, çarşı, fırın, değirmen, boyahane, salhane gibi tesisler bir şehrin çekirdeğini oluşturuyordu (Tabakoğlu, 1994:152).

Birer finansman kaynağı olarak kurulan bu müesseseler, ekonomik hayatı canlandırırken, bulundukları şehirleri de cazibe merkezi haline getirmiş, zaman içinde bu şehirler göç almaya başlamıştır. Örneğin bekâr odalarını ihtiva eden büyük hanların 
dükkânsız ve evsiz işçilerin barındıkları ve çalıştıkları yerler olması, farklı yerlerden nüfus ve emek arzına imkan hazırlıyordu. Bu odalar tezgahları ile birlikte işçiler barındırmaya uygun yapılmıştı. Çoğu vakıf olarak kurulan bu hanlarda, oldukça uygun şartlar altında çalışan işçiler, aynı zamanda toplu halde ve göz önünde disiplinli bir hayat sürmekteydiler (Barkan, 1985:41).

Bu durum sadece yeni yerleşim merkezlerinin oluşum ve büyümesinde değil, var olan yerleşim merkezlerinin hem sosyo-kültürel açıdan, hem de ekonomik açıdan cazibe merkezi olma özelliğini artırmada da kendini açıkça gösterir. Örneğin Fatih Sultan Mehmed, İstanbul'un fethinden sonra camiye çevirttiği Ayasofya'nın masraflarının finansmanı için İstanbul Bedesteni'ni, yani Kapalıçarşı' yı yaptırmıştı. Böylece oluşturulan vakıf-ticaret merkezleri İstanbul'un ve tüm ülkenin iktisadî hayatının gelişme ve canlanmasına katkı yapmıştır (Tabakoğlu, 1994:238).

Vakıflar yeni fethedilen yerlerin imar ve inşâ faaliyetleri kapsamında aktif rol oynamışlardır. Örneğin Rumeli' de fethedilen yerleşim merkezlerine pek çok kervansaray, han, köprü, imaret, misafirhane gibi hizmet sunan kuramlar inşâ edilmiş, bunlar zengin vakıf gelirleriyle finanse edilmiştir. Öyle ki, bu tür bayındırlık eserleri çerçevesinde Uzunköprü, Saraybosna ve Tatar-Pazarcık gibi şehirler oluşmuştur (Tabakoğlu, 1994:233)

Diğer yandan İslam tarihinde önemli yeri olan şehir ve yerleşim merkezleri de fetihlerle Osmanlı Devleti sinırları dahiline girdikten sonra da, yine vakıf sisteminin de katkısıyla büyük gelişmelere sahne olmuşlardır. Örneğin 24 Ağustos 1516 yılında Osmanlı ordusuyla Memluk ordusu arasında meydana gelen Merc-i Dabık savaşının ardından Osmanlı hakimiyeti altına giren Halep şehrinde, meydana getirilen vakıflar sayesinde önemli bir kalkınma gerçekleşmiştir. Hüsref Paşa, Dokagin Zade, Behram Paşa ve İbrahim Han Zade Vakıfları, şehrin sosyo-ekonomik gelişmesine önemli katkılarda bulunmuş, şehir gerek yüzölçüm, gerek nüfus, gerekse ekonomik aktivite yönlerinden ciddî sıçramalara sahne olmuştur (Bkz. Zeyn el-Abidin, 11-15).

Vakıf faaliyetleri aynı zamanda istihdam kaynağı olmuştur. Osmanlı Devletinde hemen her vakıf, bilhassa büyük vakıflar, hizmetlerin yürütülebilmesi için gerekli sayıda personelin çalıştırılması ve maaşlarının ödenmesi fonksiyonunu da yerine getirmişlerdir (Kozak, 1994:32). Eğitim, sağlık, sosyal yardımlaşma alanlardaki temel hizmetlerin yanı sıra, günümüz modern belediyelerinin yerine getirdiği ve yapmak zorunda olduğu hizmetlerden olan yol, su, sokakların aydınlatılması, park ve bahçe tanzimi gibi hizmetleri görmek için de vakıflar kurulmuş (Ertem, 2011:42), bu hizmetlerin yerine getirilmesi için çok sayıda Osmanlı vatandaşına istihdam alanı açılmıştır. Vakıflardan maaş alan görevli sayısı da bir hayli yüksek seviyelere ulaşmıştır. Örneğin, 18. yüzyılda vakıflardan maaş alanların sayısı 86.915 kişiyi bulmuştu (Güler, 2002:17)

Bütün Osmanlı şehirlerinde kurulmuş kompleks yapılar olan külliyelerin inşa edilmeleri sırasında istihdam hacminin ne denli arttığı açıktır. Ülkenin diğer bölgelerindeki ustalar ve işçiler toplanmış, ayrıca üretim kaynaklarının bulunduğu bölgelerde çalışanlar için de iş imkanları doğmuştur. Meselâ, Süleymaniye Külliyesi gibi muazzam bir yapıya gereken işgücü arzı, yalnızca İstanbul'dan değil Edirne, Bursa, Amasya, Kastamonu ve Lârende Kadılarına gönderilmiş genelgelerle buralardan sağlanmıştır. Bu olgu 
İmparatorluğu oluşturan geniş coğrafyadaki her zümreden işgücünden faydalanmak zaruretini ortaya çıarmıştır (Barkan, 1972:94).

Hemen her büyük vakıfta mütehassıs mimarlardan, su mühendislerinden, dülgerlerden, taşçı ve demirci ustalarından, kalemkârlardan, kurşunculardan, camcılardan, çinicilerden, suyolculardan, bahçe tanzim edenlerden, halı ve perde örenlerden oluşan daimi bir kadro oluşturulmuştur. Bu kadrolar vakfın mali gücüne göre genişleyip daralmıştır (Kuban, 1968:68).

Diğer yandan vakıflarda istihdam edilen ve dolayısıyla vakıflardan maaş alanların sayısındaki değişmeler, aynı zamanda vakıfların ekonomideki ağırlı̆̆ının değişmesini tespit için de değerlendirilmiştir (Buluş, 2009:27)

Tehlikeli bölgelerin güvenliği sağlamak veya yeni elde edilen toprakları şenlendirmek veya ihya etmek için kurulan derbentlerin bir kısmı, oldukça büyük vakıflar eliyle idare edilmekteydi. Her ne kadar bu vakıfların gelirleri devlet karariyla belli yerlerin vergilerinden bir kisminin buraya tahsisinden ibaret ise de, bu tür derbentlerin yerine getirdiği işlevler esasen derbent görevlileri ve derbendin bulunduğu insanlar marifetiyle yerine getiriliyordu. Bu vakıflar eliyle bâkir topraklar işlenmekle kalmıyor; ziraî sahada büyük işletmeler ve sulama tesisleri de meydana getirilmekteydi. Bazı tehlikeli yerlerde ise han, çeşme, palanka, kale, cami inşaatları ile yerleşim yerleri haline dönüşmesi sağlanmak suretiyle hem güvenli ticaret imkânı sağlanıyor, hem de konargöçerlerin veya topraksız unsurların iskânı mümkün oluyordu (Orhonlu, 1990:27-29)

Kale, istihkâm, donanma, top, gemi yapımı işlevini gören vakıflar ile lengerhane, topçular ocağı, dökümhane, saraçhane, baruthane, kılıçhane vakıfları, deniz ve kara harplerinde yararlılığı görülenlere yardım vakıfları, top çekmede kullanılan atların satın alınması ve yetiştirilmesi amacına yönelik vakıflar askerî alanda hizmet görmekteydi. Aynı zamanda askerlerin spor ve talim yapabilmesi için spor meydanlarının kurulması, yüzücülüğü, koşuculuğu, at kullanmayı, ok ve cirit atmayı teşvik için vakıfların da kurulması Osmanlı toplumunda vakıfların sadece sosyo-ekonomik açıdan değil, askerî ve güvenlik açısından da önemli bir konuma sahip olduğunu gösterir (Kunter, 1938:104).

Osmanlı döneminde şehir ve köy halkının en önemli sosyal güvenlik kurumlarından birisi de "Avârız Vakıfları" idi. Avârız, hem toplu yükümlülükler, hem de rizikolar ve tehlikeler anlamını taşır ve tamamen bir sosyal güvenlik çerçevesine giren bir uygulamadır. Şehir ve kasabaların bazı ihtiyaçlarını temin, kimsesiz ve yetimleri barındırmak için vakfedilen paralara da vakıf avarız akçası denilirdi (Kepecioğlu, 2002: 22).Sermayeleri kredi olarak işletilen avârız sandıkları ile bütün bir mahalle veya köy halkının veya içlerinden sadece fakir olanların vergi borçları ödenmekteydi. Yine umulmadık masraflarla yardımlara fon ayrılmıştı. Zamanla vergi borçlarının ödenmesi önemini kaybetmiş, su yolu ve kaldırım inşâsı, fakirlerin iâşesi, evlendirilmesi, sermaye tedariki, cenaze masraflarının karşılanması gibi hususlar ön plana çıkmıştır. Avârız sandıkları 1876-77 harbine kadar devam etmiş, o tarihten itibaren esnaf ve avârız sandıkları devlet tarafından yönetilmeye başlanmıştır. (Barkan, 1947:121)

Osmanlı uygulamasında taşınmaz mal vakıflarının en önemli kısmını oluşturan toprak vakıfları idi ve iki şekilde uygulama söz konusuydu. Birincisi, özel mülkiyet altındayken 
vakfedilen topraklardı. Bunlar özellikle tımar sisteminin bozulmasından sonra çoğalmıştı. İkincisi, devletin mülkiyetini (rakabesini) elinde tutarak vakfettiği topraklardı. Bunlara "irsâdî vakıf" da denilmekteydi ve bunların gelirlerinden hazineden alacaklı olanlar faydalanabiliyordu (Tabakoğlu, 2013:194)

Osmanlının vakıf sistemine yaptığı en önemli katkılardan birisi olarak "Para Vakıfları" gösterilebilir. Para Vakıflarının getirdiği en önemli yenilik ise, esas itibarı ile yüksek gelir sahiplerinin yapabildiği gayrimenkûl vakıflarından oluşan sektöre, küçük tasarrufları ile geniş halk kesimlerinin de katılmasını sağlayarak büyük bir genişleme ve dinamizm getirmesidir. Bu küçük tasarrufların sahipleri mevcut bir vakfa ilave yapabilecekleri gibi, aralarında birleşerek yeni vakıflar oluşturmaları da mümkün hale geldiği için vakıf sektörü muazzam bir genişleme potansiyeli kazanmıştır. Bu yolla esnaf loncaları, yeniçeri odaları, mahalleler, köyler vb. birimler yaygın şekilde para vakıfları kurup, aralarındaki dayanışmayı güçlendirerek refah ve riskleri paylaşma imkânı bulmuşlardır. Özellikle mahalle ve köylerde avârız vergilerini ödemeye yardımcı olmak üzere kurulan para vakıfları çok yaygın ve etkili olmuştur.

Para vakıfları, diğer yandan faizin yasak olduğu bir iktisadî ortamda kredi arzını artırarak ekonomiye adeta nefes alma imkânı vermiştir. Bu sayede üretim sektörlerindeki küçük ölçekli birimler, ihtiyaç duyduğu kredilere kolayca ve ucuza erişebilme imkanı bulmuşlardır (Genç, 2014:17) Bu bilgilerden hareketle para vakıflarının Osmanlı iktisadî hayatı için önemli bir finansman kaynağı fonksiyonu gördüğünü (Buluş, 2009:32) söyleyebiliriz.

\section{Vakfın Kuruluş Şekli}

Öncelikle vakfı kuracak kişinin yani "vâkıf"ın taşıması gerekli bir takım şartlar söz konusudur.

Vakıf kurucusundan vakfedeceği malın mutlak mülkiyetine sahip bulunması ve gerekli ehliyeti haiz olması istenmektedir (Ali Haydar, 1337 r./1340:134). Diğer yandan, vâkıfın hür (Ali Haydar, 1337 r./1340:21) ve âkil (akıllı) olması ayrıca erginlik çağına gelmiş bulunması; aynı zamanda, borcunu ödeyememesi ve israfı yüzünden malını kullanmaktan menedilmemiş olması da lazımdır (Ali Haydar, 1337 r./1340:120-121) Bunların dışında vakıfla ilgili diğer şartları şöyle sıralayabiliriz:

1- Vâkıfın rızası bulunması.

3- Vâkıfın mahcûr olmaması.

4- Vakf olunan mal akar veya vakfı müteârif menkul olması.

5- Vakf olunan malın ayn olup deyn (borç) olmaması.

6- Vakf olunan malın muayyen olması.

7- Vakfın müncez (yerine getirilmiş, sonuçlandırılmış) olması

8- Vakf olunan malın vâkıfın mülkü olması.

9- Vakfetme işleminde gaye kurbet (Allah'a yakınlık) ve ibadet olması.

İslâm âlimlerine göre bu şartları ihtiva etmeyen vakıf sahih değildir (Berkî, 1966:55) 
"Sahibi bulunduğu bir mülkü, ammenin menfeatine hayır ve sevap kazanmak gayesiyle ebedî olarak tahsis eden kimse" şeklinde tarif edilen "vâkıf," vakfedeceği malda bulunması gerekli bazı şartların bulunması halinde, hakime müracaat ederek vakfıyla ilgili tüm şartların kaydedildiği bir vakfiye ile tescil ettirir (Kazıcı, 1985:30-38). Ki, vakfiyeler o vakıf müessesesinin işleyişiyle ilgili günümüze kadar gelen en önemli bilgi kaynağ1 (Köprülü, 1938:4) olma özelliğini taşır.

Vakfiye, vakfın kurulması ve tüzel bir kişilik kazanmasını sağlayan hukuki bir metin ve vakıflara varlık veren resmî belgedir. Vakfiye hukukî tâbirle vakfın tescilidir. Vakfı kuran kimsenin adı, sanı, vakıf yönetimlerine sınırlı olarak bırakılmış hareket alanı içinde; vakfedilen malların veya paranın miktarı, nev'i ve evsafı, bunların geliriyle yapılacak işler ve benzeri gerekli hususlar vakfiyelerde yazılıdır. İstihdam edilecek kadrolar, ödenecek maaşlar günlük olarak verilecek yemeklerin niteliği, satın alınacak malların neler olması gerektiği... bütün bu işlemlerle ilgili olarak tutulacak muhasebe kayıtları ve yöneticilerin atanma yöntemleri ayrıntıları ile kaydedilir (Şensoy, 2016:43).

Vakfiyeler umumiyetle kâğıt veya deri üzerine yazılmıştır. Nadiren taş üzerine kazılmış olanları da vardır. Taş üzerine yazılanların bazıları vakfiyenin tam metni bazıları da hulâsasıdır. (Kunter, 1938:116).

Vakfiyede bulunması gereken temel unsurlar ise şunlardır:

1 - Allah'a hamd-ü sena ve vakfın ecr-u sevabı hakkında vârid olan ayet ve hadisler.

2 - Vakf olunan mallar.

3 - Vakf olunan malların nasıl idare olunacağı.

4 - Vâridatın sarf yeri.

5 - Vakfın kimler tarafından idare olunacağı, müessesede kaç adamın çalışacağı, bunlara ne kadar aylık verileceği, bu aylıkların nerelerden alınacak gelirlerle temin olunacağı ve sonunda bu müesseseden kimlerin ne şekilde faydalanacağına dair bir takım kayitlar ve şartlar.

6 - Hakimin vakfın sıhhat ve lüzumuna dair hükmü.

7 - Sonunda tarih ile üst kısmında hakimin mührü (Berkî, 1966:57)

Vakfiyeleri meydana getiren ana bölümler üç tanedir:

1 - Dibace (Giriş) : Vakıfın vakfı kurmasının sebebini içine alan bu bölüm çok defa ayet ve hadislerle güçlendirilir.

2 - Vakıf müessese ve vakfiyenin hizmet şartları, gelir kaynakları ve masraf yerlerinin ihtiva ettiği ikinci bölüm vakfiyenin en uzun kısmını teşkil eder.

3 - Sonuç kısmında müessesenin şeriata uygunluğu belirtilerek sonunda tarih ve şahitlerin imzaları bulunur (Kazıcı-Şeker, 1981:245) 


\section{Vakıflarda Denetim Mekanizması}

Osmanlı Devleti, üretim faktörlerini kontrol altına almaya çalışmış, ama onları kullanarak maaşlı memur ve işçilerle ile üretime girmekten genellikle kaçınmış ve bu işi mümkün olan her durumda özel şahıslara, özellikle reayaya havale etmeyi tercih etmiştir. Devlet işletmesi olarak çalıştırılması halinde hem verimsiz, hem de suistimallere açık bir rejime kapı açma ihtimalinden hareketle, eşitlikçi yapıyı bozmayacak, ama aynı zamanda özel menfaat motifini de canlı tutarak verimli işletilmesini sağlayacak ideal formül olarak bu yatırımları yapma işini vakıflara emanet etti. Bu fonksiyonlarını hakkı ile ifa edebilmeleri için de vakıfları devletin doğrudan yönetimi dışında bir otonomiye kavuşturdu. Devlet, vakfiyelerin şartlarına göre yönetilmelerine ve yıllık muhasebelerinin düzgün olarak yapılmasına, bürokrasinin tepesinde yer alan vakıf nazırları ve yarg1 sisteminin sürekli kontrolü sayesinde, şartlara aykırı hareketleri engelleyici kontrollerin dışında bir müdahalede bulunmadı (Genç, 2014:16).

Osmanlı vakıf sistemi özerk ve demokratik bir 'sivil toplum' sistemi olmakla birlikte, devlet denetimi dışında değildi. Nezâret kurumu bu denetimi sağlamaktaydı. Özellikle büyük vakıflar sadrazam, şeyhülislam, başdefterdar, kadı, Enderun, dar'us-saâde ve babu's-saâde ağaları, iç hazinebaşı, nakîbü'l-eşrâf gibi devlet görevlilerinin denetim ve kontrolü altında bulunuyordu (Tabakoğlu, 2013:193).

İdari ve mali açıdan devlete karşı özerkliği olan vakıflar, "Kadı"lar veya "Naib"leri tarafından kontrol edilmiş, denetlenmiştir. Denetlemenin ana dayanağ1 mütevellilerin tuttuğu muhasebe belge ve kayıtlarıdır. Vakıfların yıllık muhasebeleri bulundukları yerin kadısına ulaştırılmış, böylece denetim mekanizması başlatılmıştır. Vakfın "Nâzır"ı da gelir ve giderleri denetlemiş, bu akışta bir dengesizlik olmadıkça müdahale etmemiştir. Mütevelliler vakfın genel sorumluluğunu taşımış, mütevelli heyetin teklifi ve Merkez'in onayıyla atanmış katipler ise vakıf muhasebesinin sorumluluğunu üstlenmişlerdir (Bülbül, 1999:165).

Vakıflarda denetim mekanizması, birbirini ardınca devam eden ve birbirini tamamlar bir görünüm içinde gerçekleşmiştir. Öncelikle mütevelliler, kendi yönetimlerinde bulunan vakıf memurlarını denetler. İkinci kademede nâzır mütevelliyi, vakıftan yararlanma hakkına sahip olanlar nâzırı, hakim veya hükümetlerin göndereceği memurlar bunların hepsini denetler; mütevellinin muhasebesini ve diğer işlemlerini görürler (Öztürk, 1995:211).

Tarihsel süreçte vakıfların teftiş ve kontrolünü, vakıf kurucularının tayin ettikleri nâzırlar, devletçe vakıfları kontrol için görevlendirilen müfettişler ve kaza teşkilatı mensubu hakimler yürütmüştür. Müfettişlik makamı, geçici bir denetleme makamıdır ve Nâzır'ın yanı sıra denetleme işlevini görmüştür. Genelde Kadı'ların tayin edildiği bu makama kimi zaman farklı görevliler de tayin edilmiştir (Şensoy, 2014:85).

Vakıflar faaliyetlerinde, özellikle iki kesimden gelebilecek şikâyetler karşısında devletin kontrol mekanizması işlemekteydi. Vakıfları şartlara uygun harekete zorlayan iki önemli toplumsal grubun tutumları son derece etkili birer kontrol mekanizmasını oluşturuyordu. Vakıf yöneticisi, gelirlerini toplarken halka veya esnafa bir haksızlık yaptığı takdirde hemen şikâyete hedef olmaktaydı. Osmanlı reâya ve esnafının, zannedildiği gibi 
hiç de uysal insanlar olmadıkları, çok çeşitli şikâyet davalarından rahatlıkla anlaşılmaktadır. Vakfın harcamalarından yararlanan "murtezika" denen grubu ise, en ufak haksızlık karşısında sert tepki gösteren bir baskı unsuru olarak, vakıf idarelerini meşrûiyet sınırlarına çekmekte önemli rol oynamıştır (Genç, 2014:16).

Padişahların, hanım sultanların ve bazı devlet adamlarının vakıfları, 1586'da kurulan Harameyn Nezâreti tarafından denetlenmişti. Darüssâde Ağaları tarafından yönetilen bu nezâret, vakıfların denetim işleri görmek üzere "Evkâf-1 Harameyn Müfettişliği, Evkâf-1 Harameyn Muhasebeciliği, Evkâf-ı Harameyn Mukataacılığı, Darüssâde Yazıcılığı" adıyla 4 daire oluşturulmuştu (Güran, 2006:57).

\section{Sonuç}

Sadece Allah rızasını kazanmak için, zengin kimseler tarafından kurulan ve menfaati tamamiyla ihtiyaç içinde bulunanlara tahsis edilen müesseseler anlamına gelen vakıf, bir malın kamu hizmetine tahsis edilmesi esasına dayanmaktadır. İslâmın, yardımlaşma ile ilgili emir ve prensiplerinden doğan vakıf sisteminin temelini Kur'an ve Sünnet'ten hareketle şekillenen "Sadaka-i Câriye" anlayışı, yani vakıf tahsisinde bulunan kişiye hayrının sonsuza kadar devam edeceği fikri teşkil etmiştir.

Osmanlı Devletinde eğitim ve sağlık hizmetleri ile dinî ve kültürel faaliyetlerin finansmanı merkezî bütçeden değil, günümüzde üçüncü sektör olarak adlandırılan vakıflar aracılığıyla gerçekleştirilmekteydi. Dolayısıyla vakıflar, kâr imkanı bulunmayan ya da kâr marjının düşük olması nedeniyle iktisadî açıdan yatırımın cazip olmadığı sosyal hizmet faaliyetlerin finansmanında önemli bir rol oynamıştı.

Han, hamam, çarşı, zıraî topraklar gibi taşınmazların gelirleriyle "müessesât-1 hayriyye", diğer bir ifadeyle hayır kurumlarının finanse edilmesi söz konusu olmuş; tarım işletmeleri, araziler üretim kaynakları olarak düzenli gelir sağladıkları gibi toprağın vergi gelirleri de bu amaçla kullanılmış, hattâ köyler, karyeler, içindeki meskenler, tarlalar, çayırlar, kuyular, nehirler, vadiler... bütün hak ve hukukuyla vakfedilmiştir.

Osmanlılar kurmaya çalıştıkları eşitlikçi sosyal-iktisadî yapı ile birlikte devletlerini de uzun ömürlü kılmakta vazgeçilmez fonksiyonlarını gördükleri vakıf sektörünü önemli katkı ve yenilikleri ile geliştirdiler. Hâkim oldukları bölgelerde daha önceki İslâm toplumlarının kurmuş oldukları vakıfları itina ile korumakla yetinmediler; onu sosyal ve iktisadî hayatın hemen her alanında büyük bir yoğunlukta yaygınlaştırdılar. Yüzyıllar boyunca milyonlarca kilometrekarelik hakimiyet alanı dahilinde pek çok mescid, türbe, ribat, tekke, medrese, mektep, köprü, sulama kanalı, su yolu, kervansaray, hastane ve imaret gibi dinî ve hayrî müesseseyi vakıf kurumu sayesinde vücuda getirdiler.

Osmanlı toplumunun tesisi ve işleyişinde, memleketin imar ve inşasında önemli rol oynayan vakıflar, bir sosyal güvenlik kurumu olmanın yanı sıra, Osmanlı şehirlerinin oluşum ve gelişmesinde önemli bir rol üstlenmişlerdi. Genellikle her yerleşim merkezinde bir cami ve o camiin etrafında oluşturulan medrese, kütüphane gibi eğitim kurumlarıyla hastane, hamam, aşevi gibi çeşitli hayır kurumları bir "külliye" çatısı altında inşâ ediliyor; bu kurumların tüm gider ve harcamalarını finanse etmek için de yine vakıf içinde yer verilen han, çarşı, fırın, değirmen, boyahane, salhane, debbağhane gibi tesisler bir şehrin çekirdeğini teşkil ediyordu. Bu yönüyle vakıflar kuruldukları şehrin ekonomik hayatı 
canlandırırken, o şehri bir cazibe merkezi haline getiriyor, zaman içinde bu şehirler göç almaya başliyordu.

Vakıf faaliyetleri aynı zamanda istihdam kaynağı olmuştur. Osmanlı Devletinde hemen her vakıf, bilhassa büyük vakıflar, hizmetlerin yürütülebilmesi için gerekli sayıda personelin çalıştırılması ve maaşlarının ödenmesi fonksiyonunu da yerine getirmişlerdir.

Vakıfların, ülke güvenliğine de katkısı söz konusudur. Tehlikeli bölgelerin güvenliğini sağlamak veya yeni elde edilen toprakları şenlendirmek veya ihya etmek için kurulan derbentlerin bir kısmı oldukça büyük vakıflar eliyle idare edilmekteydi. Kale, istihkam, donanma, top, gemi yapımı işlevini gören vakıflar ile lengerhane, topçular ocağı, dökümhane, saraçhane, baruthane, kılıçhane vakıfları, deniz ve kara harplerinde yararlılığı görülenlere yardım vakıfları, top çekmede kullanılan atların satın alınması ve yetiştirilmesi amacına yönelik vakıflar askerî alanda hizmet görmekteydi.

Her hayır müessesesinin bir vakfiyesi bulunmakta ve bu vakfiyede müessesenin çalışma şekli ile hayır faaliyetlerinin yürütülmesi için yapılacak masrafları karşılayacak yapılar, vakıf kapsamındaki kurumlar tek tek ifade edilmekteydi. Vakfiyede ayrıca vâkıfın şartlarına göre kurumun nasıl işleyeceği, kimlerin istihdam edileceği ve ne kadar maaş alacakları detaylı olarak yer almaktaydı.

Osmanlı vakıf sistemi özerk ve demokratik bir 'sivil toplum' sistemi olmakla birlikte, devlet denetimi dışında değildi. Nezâret kurumu bu denetimi sağlamaktaydı.

\section{Kaynakça}

Ali Haydar, Hoca Emin Efendizâde (1337 r./1340), Tertibü's-sunûf fî Ahkâmi'l-Vukûf, İstanbul: Şirket-i Mürettibiye Matbaası.

Atılgan, Ahmet (1996), İslâmın Ekonomik Politikaları, İstanbul: Nesil Yayınları.

Barkan, Ömer Lütfi (1942), “Osmanlı İmparatorluğunda Bir İskân ve Kolonizasyon Metodu Olarak Vakıflar ve Temlikler", Vakıflar Dergisi, Sayı:2, ss. 279-386.

Barkan, Ömer Lütfi (1947), "Avârız", İktisat ve Ticaret Ansiklopedisi, C. II, İstanbul: İktisat ve Ticaret Ansiklopedisi Yayınları.

Barkan, Ömer Lütfi (1972), Süleymaniye Camii ve İmareti İnşaatı, Cilt: 1, Ankara: Türk Tarih Kurumu.

Barkan, Ömer Lütfi (1963), "Şehirlerin Teşekkül ve İnkişafı Tarihi Bakımından: Osmanlı İmparatorluğu'nda İmaret Sitelerinin Kuruluş ve İşleyişi Tarzına Dair Araştırmalar", İktisat Fakültesi Mecmuası, Cilt: 23, Sayı: 1-2, ss. 239-296.

Barkan, Ömer Lütfi (1985), “Osmanlı İmparatorluğu'nda Esnaf Cemiyetleri”, İstanbul Üniversitesi İktisat Fakültesi Mecmuası, C. 41, Sayı: 1-4, ss. 39-46.

Berkî, Ali Himmet (1940), Vakıflar, İstanbul: Cihan Kitaphanesi.

Berkî, Ali Himmet (1966), Vakfa Dair Yazılan Eserlerle Vakfiye ve Benzeri Vesikalarda Geçen Istılah ve Tabirler, Ankara: Vakıflar Genel Müdürlügü Neşriyatı. 
Berkî, Şakir (1969), "Vakfın Mahiyeti”, Vakıflar Dergisi, Vakıflar Genel Müdürlüğü Yayınları, C. 8, ss. 1-8.

Bilmen, Ömer Nasuhi (1970), Hukuk-u İslâmiyye ve Istılahât-1 Fıkhıyye Kâmusu, İstanbul: Bilmen Yaymevi.

Buluş, Abdülkadir (2009), “Sivil Toplum Kuruluşlarına Tarihsel Bir Örnek: Osmanlı Vakıfları", Sosyal ve Ekonomik Araştırmalar Dergisi, Sayı: 16, ss, 21-36.

Bülbül, Yaşar (1999), "Klasik Dönem Osmanlı Muhasebe Sistemi”, Dîvân, Sayı: 6, ss. 151182.

Ergin, Osman Nuri (1936), Türkiye'de Şehirciliğin Tarihî İnkişafı, İstanbul: İstanbul Üniversitesi Hukuk Fakültesi İktisat ve İçtimaiyat Enstitüsü Neşriyatı.

Ertem, Adnan (2011), “Osmanlı'dan Günümüze Vakıflar”, Vakıflar Dergisi, Sayı: 36, ss. 2565.

Genç, Mehmet (2000), Osmanlı İmparatorluğunda Devlet ve Ekonomi, İstanbul: Ötüken Yayınları.

Genç, Mehmet (2014), "Klâsik Osmanlı Sosyal-İktisadî Sistemi ve Vakıflar”, Vakıflar Dergisi, Sayı: 42, ss. 9-18.

Güler, Mustafa (2002), Osmanlı Devleti'nde Harameyn Vakıfları (XVI-XVII. Yüzyıllar), İstanbul: Tatav Yayınları.

Güran, Tevfik (2006), Ekonomik ve Mali yönleriyle Vakıflar-Süleymaniye ve Şehzade Süleyman Paşa Vakıfları, İstanbul: Kitabevi Yayınları

Kazıcı, Ziya (1985), İslâmî ve Sosyal Açıdan Vakıflar, İstanbul: Marifet Yayınları.

Kazıcı, Ziya - Şeker, Mehmet (1981), İslam Türk Medeniyeti Tarihi, İstanbul: Çağrı Yayınlar1.

Kepecioğlu, Kamil (2002), Tarih Lûgati, Osmanlı Tarih Deyimleri ve Temel Terimleri Sözlüğü, Ankara: 21.Yüzyıl Yayınları.

Kozak, İ. Erol (1985), Bir Sosyal Siyaset Müessesesi Olarak Vakıf, Ankara: Akabe Yayınları.

Köprülü, Fuat (1938), "Vakıf Müessesesi ve Vakıf Vesikalarının Tarihi Ehemmiyeti", Vakıflar Dergisi, Sayı: 1, ss. 1-6.

Köprülü, Fuat (1942), "Vakıf Müessesesinin Hukukî Mahiyeti ve Tarihî Tekamülü", Vakıflar Dergisi, ss. 1-36.

Kuban, Doğan (1968), “Anadolu-Türk Şehri: Tarihî Gelişmesi, Sosyal ve Fizikî Özellikleri Üzerinde Bazı Gelişmeler.", Vakıflar Dergisi, Sayı: 7, ss. 53-73.

Kunter, Halim Baki (1938), “Türk Vakıfları ve Vakfiyeleri Üzerine Mücmel Bir Etüd”, Vakıflar Dergisi, Cilt: 1, ss. 103-129.

Müslim bin el Haccâc Ebu'l-Hüseyin el-Kuşeyrî (1981), Sahih, İstanbul: Çağrı Yayınları.

Orhonlu, Cengiz (1990), Osmanlı İmparatorluğu'nda Derbend Teşkilatı, İstanbul: Eren Yayınları. 
Öztürk, Nazif (1995), Elmalılı M. Hamdi Yazır Gözüyle Vakıflar, Ankara: Türkiye Diyanet Vakfı Yayınları.

Şahin, Musa (1986), “Sosyal Değişmede Vakıfların Rolü”, Sosyoloji Konferansları Dergisi, Sayı: 21, ss. 231-247.

Şensoy, Fatma (2014), “Muhasebe Defterlerinden Vakıfların Çok Yönlü Boyutlarını İzlemek- Bir Örnek XVIII. Yy.", Muhasebe ve Finans Tarihi Araştırmaları Dergisi, Sayı: 7, ss. 76-103.

Şensoy, Fatma (2016), “Osmanlı İmparatorluğu'nda Vakıfların Ekonomik Boyutları", Muhasebe ve Finans Tarihi Araştırmaları Dergisi, Sayı: 10, ss. 41-63.

Tabakoğlu, Ahmet (1994), Türk İktisat Tarihi, İstanbul: Dergâh Yayınları.

Tabakoğlu, Ahmet (2004), "Klâsik Dönem Osmanlı Vakıf Sistemi”, Cumhuriyetin 80. Yılında Uluslararası Vakıf Sempozyumu Kitabı, Ankara: Vakıflar Genel Müdürlügü.

Tabakoğlu, Ahmet (2005), İslam İktisad1 - Toplu Makaleler II, İstanbul: Kitabevi Yayınları.

Tabakoğlu, Ahmet (2013), İslam İktisadına Giriş, İstanbul: Dergâh Yayınları.

Yediyıldız, Bahaeddin (1982), “Türk Vakıf Kurucularının Sosyal Tabakalaşmadaki Yeri 1700-1800", Osmanlı Araştırmaları, C. III, ss. 143-164.

Yediyıldız, Bahaeddin (1986), “Vakıf” Maddesi, İslam Ansiklopedisi, İstanbul: Milli Eğitim Basımevi, ss. 153-172.

Zaim, Sabahaddin (1987), "Vakıfların Milli Ekonomiye Etkileri", Ankara: Vakıf Haftası Dergisi, Sayı: 5, ss. 209-213.

Zeyn el-Abidin, Mahmut, “16. Yüzyılda Halep'in Çarşılarının Gelişmesinde Osmanlı Vakıflarının Rolü", https://www.academia.edu/20131854/16.Y\%C3\%9CZYILDA HALEP $\% 4 \% B 0 N \%$ C3\%87AR\%C5\%9EILARININ GEL\%C4\%B0\%C5\%9EMES\%C4\% BONDE OSMANLI VAKIFLARIN ROL\%C3\%9C, Erişim Tarihi: 13 Temmuz 2017. 